\title{
kreoling sisters (Un)intimate relationships, child marriages and women spirits
}

\author{
Gitan Djeli \\ Gitan Djeli is an affiliate art history fellow, Indian Ocean Exchanges \\ Program, supported by Harpur College, Binghamton University and \\ the Getty Foundation
}

\begin{abstract}
The non-fiction piece, 'kreoling sisters', explores the overlapped histories of slavery and indenture in the Indian Ocean context, Mauritius in particular. It merges memoir writing, indenture studies and Black study and theory to discuss antiblack/antikreol racism and unfreedom during the critical historical time between the beforelife of indenture (that is slavery) and the afterlife of slavery during indenture. 'kreoling sisters' unearths a personal story that touches on the (un)intimacy or unofficialised intimacy between Black mothers and men of Indian descent and their Black-Indo/Kreol children. The aim is to discuss the entanglement between freedom, intimacy, slavery, antiblackness and indenture and disrupt the official, institutional, colonial and patriarchal narratives. The question the piece finally asks is how intimacy and love can exist, with the thought of what freedom could have been in the colony and could be in contemporary times. 'kreoling sisters' wishes to envision how Indenture studies can engage with a Black philosophy of freedom and abolition, that is the abolition of the plantation police, prison and property, inherited from colonialism.
\end{abstract}

\section{KEYWORDS}

intergenerational silences, Indo-Kreol relations Mauritius, indenture Mauritius, Indo-Mauritian, Afro-Asian relations 
Without freedom, love and intimacy don't matter. (Spillers 2018)

Women who survived the absence of their sea-faring men easily, because they came to love each other, past the men's returning. (Lorde 1993: 14)'

Sister, my uncle stressed, not demiser.

He was right. What is a half-sister? There was nothing half about Monol, a sister he had met for the first time in his sixties; a sister, two years older than him, who was born before his mother, my grandmother, was brought in to be the official wife.

I found out about Monol while researching for a non-fiction piece that traced my matrilineal genealogy, up to the first woman who reached mainland Mauritius under indenture (Djeli 2018: 10). I mentioned her to highlight how the official family erased her and her mother from the family narrative. I did not name Monol in the piece because I believed, then, that it was not for me to tell her (and her mother's) story, while she was still alive. The piece was after all about conjuring four undead ancestral grandmothers who were no longer of this world. Looking back now, I wonder whether I was ready to have an intimate conversation with Monol, my aunt, about the wounds that still persist today.

'kreolings sisters: (un)intimate relationships, child marriages and women spirits' is about the (un)intimacy of officialised relationships as well as the intimate history I, as a writer and scholar, strive to weave with the help of Black study and theory and indenture studies. 'kreoling sisters' engages with a line of thought developed by Professor Hortense Spillers, Black feminist scholar and American literary critic, who examines the shadow family within the plantation, where children born of an enslaved mother and a slave owner lived in the shade of the enslavers' family. ${ }^{2}$ In particular, Spillers studies how this strand of sociality continued/s after the abolition of slavery. 'kreoling sisters' reveals the continuation of that unofficial intimacy in the immediate afterlife of slavery, during indenture, between Black mothers and men of Indian descent and their Black-Indo/Kreol (Black Creole) children. This piece is a process of attentively (un)writing the silencing of 
Monol and her mother in the family archive - to understand the entanglement between freedom, intimacy, slavery, antiblackness and indenture and to disrupt official, institutional, colonial and patriarchal narratives.

During a long phone conversation with my uncle on my wish to speak to Monol, he proposed I call her. The 'first' time Monol met him and his brother, she had seemingly been enthusiastic about the reunion with the officialised sons. Monol had welcomed them in her one room corrugated iron-sheet house on the periphery of the emerging bourgeoisie of Goodlands' indentured workers, where my uncle was born. He believed that she did not seem to bear a grudge. What else could Monol have done? I wonder. How she really felt about meeting two old men, whom she had played with on the streets as a child, whom she knew were her father's children and lived with him, I will never know. When my uncle was 5 , his mother, my grandmother, died at the age of 26 after a decade of being the official wife. She gave birth to eight children who left Goodlands shortly after her death, to move to a colonial house in town with their grandfather. The older siblings' memories of playing with Monol faded away. But Monol always remembered that the man with the eight children in the big house was her father.

It took me weeks to call Monol. She is in her early eighties and is 9,000 kilometres away. A random phone conversation from the UK (under lockdown) with a granddaughter from her father's official family, a woman she does not know, seemed to me inappropriate and intrusive. How would she feel about it? Why would she want to remember the past again? Despite the apprehension, a set of open questions haunted me, from how her mother felt about being shadowed by her father to whether she wanted to talk about discrimination, prejudices, antiblackness and antikreol racism on the island. I was desperate to hear, first-hand, the implications of race and gender in the afterlife of slavery, by enquiring about the shadow relationship between her and her father, between her mother and her father, and maybe between her mother and my grandmother. 
Implications that my uncle was also familiar with. He had himself fallen in love and married a Kreol sega activist singer in the 1970s with whom he has a daughter. My uncle had trespassed the boundaries of maraz (Brahmanical) casteist Hindu ideology, fixed in place in an indenture society founded on a colonial legacy of antiblackness. I grew up in the intimacy of their relationship, as much as in the violence of the hate and spite conferred on the couple by both close and extended family. They are not together any more but have remained very good friends. My uncle tells me how he has faced and still faces ingrained antikreol/antiAfrican racism in Mauritius after his second marriage to a Mozambican woman of Emakhuwa ancestry, which makes him sensitive to what his father would have experienced in the 1940s. Unlike him, his father did not stand by the woman who birthed their daughter, Monol. My uncle tells me that Monol looked like their father and when he met her, when the officialised sons met her, she asked, with humour, that they acknowledge her as their father's first child. Before I gathered courage to dial her number, I wondered how intimate I was to her, to ask permission to write her into the family story.

When I finally called her landline, I was confronted by a cold, corporate, automated voice: 'this number is out of service'. A friend of mine, on the island, tried the number and got the same message. It was probably a sign I told myself: I should not call her. A split second of relief was followed by a restlessness to find out why her phone was not working. My uncle eventually proposed I call his cousin who knows Monol and lives nearby. He is also in his eighties and when I reached him, it was 7pm on his side of the world. He seemed happy to chat with 'the young generation' interested in the family history, but he politely told me that he would soon go to bed. I informed him that I was trying to contact Monol. He paused for a few long seconds, then apologised and stated, as a matter of fact, that Monol had died two years ago.

I was not prepared for this. How did she die? How come my uncle did not know? I had hoped my uncle's cousin would tell me she had changed her number. I had hoped to hear her, eventually, hear the tone of her voice, the tremor, the nostalgia, the resilience or the sadness. 
In my previous piece, Mother Wounds, I unearthed the stories, the ghosts of four ancestral grandmothers from the silences of the archives. Was I to conjure another spirit, this time of an ancestral aunt?

My uncle's cousin was talkative. He knew Monol and her mother well. Monol's mother used to live a couple of streets away, in the concrete site (pronounced si-teh, or the ghetto) of St Claire. This is the racial border, created under European colonisation, that stratified the cartography between the Kreol si-teh and the Indian gaawn, determined (still) by the names of streets running parallel to each other. As children, Monol and my uncle were already aware of that (un)intimacy, what Professor Saidiya Hartman, scholar of African American and American literature and cultural history, describes as the interracial sum razed and mapped into homogeneous zones of absolute difference. ${ }^{3}$ For Hartman, the public intimacy of the ghetto was a space of encounter where intimate life unfolds in the street, where we can only imagine the things whispered in dark bedrooms and speculate the modes of escape and possibility. This intimacy in the street is, I believe, also steeped in what cannot continue to be intimate. When I asked my uncle's cousin whether he knew if Monol's father was in love with Monol's mother, he was dismissive: Monol's mother was a Kreol woman; his cousin was young; it happened before he got married; besides Monol's mother married after. Other members of the family I discussed it with had similar reactions: what he did when he was young does not concern us.

As if a man's youth was permission to dismiss Kreol love and motherhood, to be indifferent to Kreol pain, indifferent to the shadow children born out of these relationships. ${ }^{4}$ Was Monol's mother desired and not loved? Was my grandmother accepted but not desired? Both women were courted differently within the patriarchal convention of intimacy. ${ }^{5}$ In the postcolony, caste, class and antiblackness seep into the veins of the plantation structure (still in place) and predetermine who can be officially courted and who must be desired in private. I am thinking of Monol's mother, who brought Monol up alone in close proximity to the official wife. I am thinking of my grandmother who spent a decade in pain carrying eight children and who succumbed a 
few days after her last one. I am thinking of the violence behind both shadowed and officialised intimacy, policed by both the women and men in the household. Did my grandmother, destined to be a young wife of the rising Indo-Mauritian bourgeoisie, try to connect with Monol's mother, shadowed by her husband's family, such shadowing normalised, suffered, endured, held on to, untended to?

In the process of writing this piece, I found out that a nephew of Monol's father also loved a Kreol woman and they had a son. Supposedly everybody knew, but nobody spoke to or about him. The son died unacknowledged by the father who, in turn, confessed on his deathbed of a lifetime of sorrow for the pain he caused his son and the latter's mother.

The interstices of antikreol racism reproduced amongst the indentured upper castes is very evident where the official acceptance of fleshy (un)intimacy (Black-Indo romance and the children birthed) is concerned. It is the (un)intimacy of blood, semen, exchange of fluids, passion, desire, history, neighbourhood, soil and family that I unpack here. It is also the intimacy of attraction, flirting, touching, feeling in the colony despite the pre-emptive violence to its existence. Part of me wants to believe that Monol's father desired and loved Monol's mother, that he was compelled to marry my grandmother, that he was not complicit with his parents who secretively sent money and food to Monol's mother, that he was not a coward. But Monol's father was apparently 'enn coureur de jupons', a womaniser. This was told to me with all the codes of normative heteropatriarchy, the humour around him having several women because he was after all involved in natak, a form of dramatic theatre from the subcontinent that involved cross-dressing.

'Without freedom, there is no love and intimacy', I start and return to Spillers' framework. 'kreoling sisters: (un)intimate relationships, child marriages and women spirits' took shape under the revelation of another story. In my previous writing, I wrote that my great-grandmother 'had left twice' before settling down with the family where she would birth my grandmother. This is what I deduced from a recording by a family member who spoke to my great-grandmother's sister-in-law. I have played the video on repeat 
and discussed the conversation with the interviewer. We both understood that she had left twice. We could not find any other explanation other than that she had left two different men/husbands/ households. A new narrative emerged when a relative informed me of a post on social media by a nephew of my great-grandmother. He paid tribute to her and posted a faded black and white photograph of her in her old age. In it, she is wearing a white sari, her hair is short, and she wears no jewellery. She looks as stern as the picture I have of her as a young mother. She still has the same presence though, and her light eyes captivate even more. From there, I started a conversation with the nephew and my grandmother's youngest sister, the only sibling still alive who was unavailable when I wrote Mother Wounds. She confirmed that the two households her mother had left had been the house of the same man, whom she returned to for good the third time.

What I was not prepared for was to be informed that my greatgrandmother was a child-wife who was sent to her future husband's household at the age of 9. When she left that house for the second time, my great-grandfather was remarried to another girl, who died shortly after. How she died, we might never know. My great-grandmother was sought after once more. She was 18 by then. In this case, it was not the shadowed intimacy of the Kreol mother and child, but the violence behind the (un)intimacy of child marriages in the Indian diasporic context. Within the plantation, intimacy was predicated upon the usefulness of black and brown women's bodies. I was not sure what was more traumatic, finding out that my grandmother may have had three husbands (an improbable speculation of mine) or finding out that she was married at 9 and left twice to be returned, faute de mieux, to the family. ${ }^{6}$ Perhaps, I was enamoured of the possibility of her having had some agency in refusing men who were unfit for her, rather than the triumphant narrative of romance, of her being destined for just one man? Perhaps, I should nurture the thought that Monol's mother was not shadowed, a narrative where she has no agency, but perhaps she refused men who were not fit to stand by her and with her? 
How could intimacy and love exist, in the immediate afterlife of slavery, that is indenture? How could there be intimacy and love in my great-grandmother's child marriage or in my grandmother's marriage? Monol's mother lived only a few houses away and woke up every day, possibly carrying baby Monol under her arms, to fetch water from a tap provided by the official family. My uncle's cousin informed me that his family's house had plumbing and that they had a tap outside for the neighbours, whose only other access to water would have been the river. Monol's mother was also a labourer. Who looked after the child when she went to the fields? Drawing from Audre Lorde, I hope other women, who love each other, supported her.

When my grandmother died, Monol's father stayed in Goodlands to run a shop his family had set up. Monol remembered going to see him in the shop. My mother remembered seeing him on Sunday, when he visited his motherless children in town. My mother found out the Sunday visitor was her father when she was about 5 . When I met my mother's family in its entirety at my grandfather's deathbed, Monol, the first daughter, was not present. I can only hope that when she died two years ago, she was surrounded by loved ones.

'kreoling sisters: (un)intimate relationships, child marriages and women spirits' is a request for the undead to be written into the family history. While most of the descendants of the (un) dead women in my family buried the latter's lives in the private realm of officialised (un)intimacy, I decide to unearth them, dig the archives, excavate bones, imagine their lives, speculate, critically fabulate, wake up/talk to their spirits. ${ }^{7}$ But should I have? What if they did not want to be summoned? On the other hand, what if they are summoning us to write their stories? What if their spectral photographs and their absence in the present ask us to not only remember them, but free them. Maybe we conjure them to make a point, to bring comfort, to break the colonial archive, to collectivise, to redress, to repair, to honour them, to ask them for clarifications, to discuss, retort, question, like every younger generation does. 
While I wrote this piece, I watched Spirited Away. It made me reflect on the spirits who walk the earth and return to their hometown, animated by the furusato during the Japanese Obon season. It made me think of the rituals our indentured ancestors transmitted to us, on how to live with the roaming spirits on the island, such as la dame blanche, the white lady, the churail, the female spirit who stays with us because she died tragically. Hartman tells us that we rouse the spirits of the enslaved because we are the hunger of the dead, that Kosanba, the spirit child, the come-go-back child, moves between the worlds of the living and the dead because of stories not passed on, ancestors not remembered, that the spirit child braves the wreckage of history and bears the burdens that others refuse (Hartman 2008a).

'kreoling sisters' wants us to imagine the spirits of Monol's mother and my grandmother being bound in a form of collective living, intimacy, love and care. kreoling, as intimate as a sister one sleeps with through childhood. As intimate as queer love, as poetic as the chirp of cardinals at dusk; probably the only time when the free and the indentured would have looked at the sky and whispered or sung in Kreol to respond to the intimacy of the flesh. kreoling, the phonetic k disrupting the $\mathrm{c}$ in the context of capturing languages in written forms, $\mathrm{k}$ representing the sound of kreol, as an island resonance, as a call. kreoling as a verb, in contrast with creolis/zing which has become a metaphor for everything and anything. ${ }^{8}$ kreoling as creating (drawing from the etymology of creole, creare, produce, create), as autopoiesis, self-creating, not so much as a conscious creative process (thinking with créolité as well here), but of auto-creation. ${ }^{9}$

Finally, what I am unpacking and inquiring in this postscript is how to engage Indenture Studies with a Black philosophy of freedom and abolition. By this, I mean the abolition of the plantation complex, a structure of oppression that was maintained by the British system of indenture after the abolition of slavery. The end of the slave trade in 1807 and slavery in the empire in 1834 was, for the colonial administrators, not about the immorality of the dehumanising system but about preventing Black revolution in the colonies (Lowe 2015: 13). The indenture experiment started 
as early as 1803 , the year that it was discussed by officials as a system that could replace the slave trade (Lowe 2015: 44). The system was strategically devised to structurally maintain the violence of the plantation, a calculus entrenched in colonial logic whereby the number of freed Black people would be replaced by Indian indentured workers. There is a critical historical point between the beforelife of indenture (that is slavery), the immediate afterlife of slavery during indenture, and freedom. The enslaved who were freed after the proclamation of the Abolition of Slavery were not liberated from the plantation structure.

To conclude I need to believe that we can imagine love in the afterlife of slavery and indenture that is intimately related to liberation from and the abolition of the plantation mode of policing intimacy.

Can our writing think with abolition of the plantation police prison and property inherited from colonialism? ${ }^{10}$

In this spirit of conjuring our ancestral mothers I ask could we also engage in a practice of intimate relating and collective mourning of the undead and finally let the spirits rest?

\section{NOTES}

1 In her poetic teachings, Lorde recollects how Carriacou women who love each other not only survive life's hardships but create joy in the fellowship of each other.

2 Spillers (2017) discusses the aftermath of the notion of partus sequitur ventrem in the Americas, which proclaimed that the child born of an enslaved mother and a slave owner would also be enslaved by the father.

3 See Hartman (2019), on Black intimate life and the ghetto as a continuation of the plantation structure.

4 I draw from the work of Hartman on Black pain here. 
5 For Spillers, public traditions of courtship assured the acknowledgement of an intimate relation unfolding, and are normalised as a kind of knowledge, or an epistemology distributed to members of a class.

6 It reminded me how, in Lose Your Mother, Hartman reviews her preliminary notes to look for a great-great-grandmother that she was convinced she had encountered. 'It was as if I had conjured her up. Was my hunger for the past so great that I was now encountering ghosts?' (2008a: 18).

7 Hartman (2008b) discusses critical speculation and fabulation as a method to write the silences in the official archives into history. See also Hartman (2021).

8 Creolizing Europe, Creolizing Hegel, Creolizing Political Theory, the list of books is endless and has nothing to do with the historical violence of the plantation on the Creole and Kreol children of enslaver fathers and Black mothers.

9 See the work of Sylvia Wynter on autopoiesis (McKittrick 2015).

10 In 'Venus in Two Acts', Hartman asks 'Must the future of abolition first be performed on the page?' (2008b). See also the work of Ruth Gilmore, Rinaldo Walcott and Ananya Roy on the abolition of prison and property.

\section{REFERENCES}

Djeli, Gitan. 2018. Mother Wounds, We Mark Your Memory (London: Commonwealth Writers/SAS Publication).

Hartman, Saidiya. 2008a. Lose Your Mother (New York: Farrar, Straus \& Giroux). Hartman, Saidiya. 2008b. 'Venus in Two Acts', Small Axe, 12(2): 1-14.

Hartman, Saidiya. 2019. Wayward Lives, Beautiful Experiments: Intimate Lives of Social Upheaval (London: Serpent's Tail).

Hartman, Saidiya. 2021. 'Intimate History, Radical Narrative', Journal of African American History, 106(1).

Lorde, Audre. 1993. A New Spelling of My Name (New York: Quality Paperback Book Club).

Lowe, Lisa. 2015. The Intimacies of Four Continents (Durham, NC: Duke University Press).

McKittrick, Katherine (ed.). 2015. Sylvia Wynter: On Being Human as Praxis (Durham, NC: Duke University Press).

Spillers, Hortense. 2017. Shades of Intimacy: Women in the Time of Revolution (New York: Bernard Center for Research on Women).

Spillers, Hortense. 2018. 'To the Bone: Some Speculations on Touch', Gerrit Rietveld Academie at Stedelijk Museum, Amsterdam, 19:30. Available at https://www.youtube.com/embed/AvL4wUKIfpo 